\title{
Non-phytate phosphorus requirement for male broilers subjected to two calcium supply regimens from 8 to 21 days of age under thermoneutral environment conditions
}

\author{
Evandro F. Cardoso ${ }^{1}$, Juarez L. Donzele², Rita-Flávia M. O. Donzele², Érika M. Figueiredo², Cândida P. F. Azevedo² \\ and Bruna L. Sufiate
}

${ }^{1}$ Instituto Federal de Educação, Ciência e Tecnologia Baiano (Campus Itaberaba), Av. Rio Branco s/n, Centro, Itaberaba 46880-000, Bahia, Brazil ${ }^{2}$ Universidade Federal de Viçosa, Dept. Animal Science, Av. Peter Henry Rolfs s/n, Campus Universitário, Viçosa 36570-000, Minas Gerais, Brazil. ${ }^{3}$ Universidade Federal de Viçosa, Dept. Biochemistry and Molecular Biology, Av. Peter Henry Rolfs s/n, Campus Universitário, Viçosa 36570-000, Minas Gerais, Brazil.

\begin{abstract}
The purpose of this study was to determine the non-phytate phosphorus (nPP) requirement for male broiler subjected to two calcium supply regimens from 8 to $21 \mathrm{~d}$ of age, based on performance and bone mineralization. Birds were distributed in a complete randomized $4 \times 2$ factorial design with four nPP concentrations: $0.25,0.35,0.45$ and $0.55 \%$, and two Ca supply regimens: Ca fixed at $9.0 \mathrm{~g} / \mathrm{kg}$ of diet $(\mathrm{CaF})$ or varying together with the nPP concentrations tested keeping a fixed Ca:nPP ratio $(\mathrm{CaV})$, with 8 battery cages/treatment and 9 birds/battery cage. Feed intake (FI), body weight gain (BWG) and Ca:P ratio deposited in the dry defatted tibia (TibCa:TibP) were quadraticaly increased by the increasing nPP concentrations, regardless of the Ca supply regimen adopted $(p<0.01)$. The nPP levels tested also influenced FCR and TibAsh, which presented a quadratic and linear response when CaF and CaV diets were used, respectively, and TibP and TibCa, which presented a quadratic response with both $\mathrm{Ca}$ supply regimen, $\mathrm{CaF}$ and $\mathrm{CaV}$ diets. $\mathrm{Also}$, $\mathrm{CaV}$ diets provided a 2.86 and 5.02\% higher FCR $(p<0.05)$ and TibCa $(p<0.01)$, respectively, when compared to CaF diets. Therefore, nPP nutritional requirement for male broilers reared at thermoneutral conditions from 8 to $21 \mathrm{~d}$ of age that provided better performance and bone mineralization were, respectively, 0.480 and $0.459 \%$ with $\mathrm{CaF}$ and $0.550 \%$ with $\mathrm{CaV}$ diets, indicating that, under thermoneutral conditions, $\mathrm{CaV}$ diets negatively affected growth performance of broilers, while positively affecting bone mineralization especially when low nPP levels are applied.

Additional keywords: mineralization; nutritional requirement; performance; thermal comfort; tibia.

Abbreviations used: aP (available phosphorus); BGTH (black globe temperature and humidity); BWG (body weight gain); CaF (fixed calcium); $\mathrm{CaV}$ (varied calcium according to non-phytate phosphorus level); FCR (feed conversion ratio); FI (Feed intake); nPP (non-phytate phosphorus; TibAsh (tibia ash content); TibCa (tibia calcium content); TibP (tibia phosphorus content).

Authors' contributions: Conceived and designed the experiment: EFC, JLD and RFMOD. Obtained funding and supervised the work: JLD and RFMOD. Performed the experiment: EFC, EMF, CPFA. Analyzed the data: EFC and BLS. Drafted the manuscript: EFC and BLS. All authors read and approved the final manuscript.

Citation: Cardoso, E. F.; Donzele, J. L.; Donzele, R. F. M. O.; Figueiredo, E. M.; Azevedo, C. P. F.; Sufiate, B. L. (2018). Non-phytate phosphorus requirement for male broilers subjected to two calcium supply regimens from 8 to 21 days of age under thermoneutral environment conditions. Spanish Journal of Agricultural Research, Volume 16, Issue 3, e0611. https://doi.org/10.5424/sjar/201816312230
\end{abstract}

Received: 05 Sep 2017. Accepted: 05 Oct 2018.

Copyright (C) 2018 INIA. This is an open access article distributed under the terms of the Creative Commons Attribution 4.0 International (CC-by 4.0) License.

Funding: FAPEMIG (Fundação de Amparo à Pesquisa do Estado de Minas Gerais).

Competing interests: The authors have declared that no competing interests exist.

Correspondence should be addressed to Evandro F. Cardoso: evandro.cardoso@ifbaiano.edu.br

\section{Introduction}

Phosphorus (P) is an important mineral required in poultry diets for normal growth and development (Ankra-Badu et al., 2004). It constitutes the costliest mineral nutrient in animal nutrition and is the third most expensive component in non-ruminant diets, where the first two are energy and protein (Boling et al., 2000).
Countless studies have been focused on the $\mathrm{P}$ requirement for poultry, not only due to its economic importance, but also due to its environmental impact. In many countries the concern is growing about the excess of this mineral in the soil due to soil and groundwater contamination (Runho et al., 2001). The phosphorous, when leached to the fresh waters, stimulates the rapid growth of algae and cyanobacteria which, due to its 
high respiration rates, leads to hypoxia, impairing aquatic life (Silva et al., 2008).

Beyond its economic and environmental importance, $\mathrm{P}$ is an essential element in the animal body for energy metabolism, synthesis of nucleic acids, and structure of cells membranes (Saraiva et al., 2012). Along with calcium, it plays a major role in the development and maintenance of the skeletal system of the animal, being the second most abundant mineral in the body. Approximately $80 \%$ of all the $\mathrm{P}$ present in the body is found in the skeletal system and, when deficient, can cause rickets, retarded growth, and other skeletal deformities (Sethi et al., 2008). Additionally, it serves as a reserve to be mobilized to fulfill functions in almost all metabolic processes, playing a vital role in almost every series of biochemical reactions in the body (Cromwell, 1989).

Calcium $(\mathrm{Ca})$ and $\mathrm{P}$ are important for the development and maintenance of the skeletal system in poultry and deficiencies in amounts or improper ratios of these two minerals usually lead to greater incidences of leg abnormalities (Xie et al., 2009).

Commonly the requirements of $\mathrm{Ca}$ or $\mathrm{P}$ are determined independently at a constant level of the other mineral ( $\mathrm{Ca}$ or $\mathrm{P})$. In fact, the requirements of $\mathrm{Ca}$ and $\mathrm{P}$ are interdependent. According to Rama Rao et al. (2003, 2006) and Xie et al. (2009) there is a significant interaction between dietary $\mathrm{Ca}$ and $\mathrm{P}$ on poultry nutrition and improper ratio of these two minerals can also depress growth performance.

Therefore, this study was designed to evaluate the impact of two $\mathrm{Ca}$ supply regimens on non-phytate phosphorus (nPP) requirement of male broilers from 8 to $21 \mathrm{~d}$ of age under thermoneutral conditions.

\section{Material and methods}

The protocol used in this study was reviewed and approved by the Animal Care and Use Committee of the Universidade Federal de Viçosa (MG, Brazil). The experiment was conducted at the Animal Bioclimatology Laboratory located at the Department of Animal Science, Agrarian Sciences Center, Universidade Federal de Viçosa, MG, Brazil to evaluate performance and bone mineralization.

\section{Animal and housing}

The 1-d-old male Cobb $500 \times$ Cobb 500 broilers (slow feathering), used in these studies, were obtained from a commercial hatchery (Rio Brando Alimentos S/A, Pará de Minas, MG, Brazil) and raised in floor pens from hatch to $7 \mathrm{~d}$ and were fed a pre-starter diet that met or exceed Rostagno et al. (2005) recommendations for all nutrients.

On d 8, 576 birds with an initial body weight of $134.92 \pm 0.32 \mathrm{~g}$ were transferred into environmental controlled chambers and allotted to one of the 64 metal battery cages $(85.0 \mathrm{~cm} \mathrm{~W} \times 85.0 \mathrm{~cm} \mathrm{D} \times 37.2 \mathrm{~cm} \mathrm{H})$, with mesh floor and supplied with hanging galvanized iron gutter type feeders and drinkers $(83.0 \mathrm{~cm} \mathrm{~L} \times 9.4$ $\mathrm{cm} \mathrm{W} \times 5.5 \mathrm{~cm} \mathrm{D})$.

For the experimental period, the climatic chambers were set to remain with a constant air temperature of $29^{\circ} \mathrm{C}$ from 8 to $15 \mathrm{~d}$ of age and $27^{\circ} \mathrm{C}$ from 16 to 21 $\mathrm{d}$ of age and relative air humidity between $55-65 \%$, featuring a thermoneutral environment condition, according to Cobb Vantress (2012).

The environmental conditions inside the climatic chambers, represented by temperature and relative air humidity, were monitored twice a day ( 7 am and 6 pm) through thermometers of dry bulb and wet bulb, and black globe (Incoterm Industry of Thermometers Ltd., Porto Alegre, RS, Brazil) kept in the center of the room. Subsequently, these data were converted to the black globe temperature and humidity (BGTH) index, as proposed by Buffington et al. (1981). The lighting program adopted throughout the entire experimental period was continuous ( $24 \mathrm{~h}$ of artificial light).

\section{Treatments and experimental design}

On day 8 , birds were assigned to eight treatments in a completely randomized $4 \times 2$ factorial arrangement with four nPP concentrations $(0.25 ; 0.35 ; 0.45$ and $0.55 \%$ ) and two Ca supply regimens, either at a fixed concentration $(9.0 \mathrm{~g} / \mathrm{kg}$ ) (Table 1), regardless of nPP concentration, or at varying concentrations, to maintain a fixed Ca:nPP ratio (Table 2). A total of 8 replicate battery cages per treatment with 9 birds per battery cage were used. Weight of the birds was similar so that both pen to pen and within pen chick weight variation were minimized. The statistical model was as follows:

$$
Y i j=\mu+\alpha i+\beta j+\gamma i j+\varepsilon i j,
$$

where $i=1,2,3,4 ; j=1,2, Y=$ mean of the experimental unit factor I and factor $\mathrm{j} ; \mu=$ constant inherent to all experimental units; $\alpha i=$ effect of level $i$ of factor $\alpha ; \beta j=$ effect of level $\mathrm{j}$ of factor $\beta ; \gamma \mathrm{ij}=$ effect of interaction between factors $\alpha$ and $\beta$; eij = error of the experimental unit factor $i$ and $j$.

During the experimental period, diets were cornsoybean meal based and formulated to meet or exceed the bird's nutritional requirement, according to Rostagno et al. (2005) recommendations, except for $\mathrm{nPP}$ and in certain cases $\mathrm{Ca}$, when diets varying $\mathrm{Ca}$ and 
Table 1. Ingredient and chemical composition of experimental diets fed to broilers from 8 to $21 \mathrm{~d}$ of age.

\begin{tabular}{|c|c|c|c|c|c|c|c|c|}
\hline \multirow{3}{*}{ Ingredient (g/kg) } & \multicolumn{8}{|c|}{ Non-phytate phosphorus levels, \% } \\
\hline & \multicolumn{4}{|c|}{$\mathrm{CaF}^{(1)}$} & \multicolumn{4}{|c|}{$\mathrm{CaV}^{(2)}$} \\
\hline & 0.25 & 0.35 & 0.45 & 0.55 & 0.25 & 0.35 & 0.45 & 0.55 \\
\hline Ground corn $(7.8 \% \mathrm{CP})$ & 487.4 & 487.4 & 487.4 & 487.4 & 487.4 & 487.4 & 487.4 & 487.4 \\
\hline Soybean meal ( $45 \% \mathrm{CP})$ & 414.7 & 414.7 & 414.7 & 414.7 & 414.7 & 414.7 & 414.7 & 414.7 \\
\hline Soybean oil & 51.2 & 51.2 & 51.2 & 51.2 & 51.2 & 51.2 & 51.2 & 51.2 \\
\hline Dicalcium phosphate & 7.4 & 12.8 & 18.2 & 23.6 & 7.4 & 12.8 & 18.2 & 23.6 \\
\hline Ground limestone & 15.7 & 12.3 & 8.8 & 5.4 & 5.4 & 7.1 & 8.9 & 10.6 \\
\hline Silica sand & 11.6 & 9.7 & 7.7 & 5.8 & 22.0 & 14.8 & 7.7 & 0.5 \\
\hline Salt & 5.0 & 5.0 & 5.0 & 5.0 & 5.0 & 5.0 & 5.0 & 5.0 \\
\hline DL-Methionine (990 g / kg) & 2.3 & 2.3 & 2.3 & 2.3 & 2.3 & 2.3 & 2.3 & 2.3 \\
\hline L-Lysine $\mathrm{HCl}(785$ g/kg) & 0.4 & 0.4 & 0.4 & 0.4 & 0.4 & 0.4 & 0.4 & 0.4 \\
\hline L-Threonine & 1.1 & 1.1 & 1.1 & 1.1 & 1.1 & 1.1 & 1.1 & 1.1 \\
\hline Mineral supplement ${ }^{(3)}$ & 0.5 & 0.5 & 0.5 & 0.5 & 0.5 & 0.5 & 0.5 & 0.5 \\
\hline $\begin{array}{l}\text { Vitamin } \\
\text { supplement }{ }^{(4)}\end{array}$ & 1.0 & 1.0 & 1.0 & 1.0 & 1.0 & 1.0 & 1.0 & 1.0 \\
\hline Coccidiostats $^{(5)}$ & 0.5 & 0.5 & 0.5 & 0.5 & 0.5 & 0.5 & 0.5 & 0.5 \\
\hline Choline chloride $(600 \mathrm{~g} / \mathrm{kg})$ & 1.0 & 1.0 & 1.0 & 1.0 & 1.0 & 1.0 & 1.0 & 1.0 \\
\hline Growth $\operatorname{promoter}^{(6)}$ & 0.1 & 0.1 & 0.1 & 0.1 & 0.1 & 0.1 & 0.1 & 0.1 \\
\hline Antioxidant ${ }^{(7)}$ & 0.1 & 0.1 & 0.1 & 0.1 & 0.1 & 0.1 & 0.1 & 0.1 \\
\hline Total & 1000.0 & 1000.0 & 1000.0 & 1000.0 & 1000.0 & 1000.0 & 1000.0 & 1000.0 \\
\hline \multicolumn{9}{|c|}{ Formulated (analyzed) $)^{(8)}$ nutrient content $(\mathrm{g} / \mathbf{k g})^{(9)}$} \\
\hline $\mathrm{ME}, \mathrm{Mcal} / \mathrm{kg}$ & 3,050 & 3,050 & 3,050 & 3,050 & 3,050 & 3,050 & 3,050 & 3,050 \\
\hline $\mathrm{CP}$ & 230.0 & 230.0 & 230.0 & 230.0 & 230.0 & 230.0 & 230.0 & 230.0 \\
\hline Digestible Met + cist & 8.4 & 8.4 & 8.4 & 8.4 & 8.4 & 8.4 & 8.4 & 8.4 \\
\hline Digestible Lysine & 11.9 & 11.9 & 11.9 & 11.9 & 11.9 & 11.9 & 11.9 & 11.9 \\
\hline Digestible Threonine & 7.8 & 7.8 & 7.8 & 7.8 & 7.8 & 7.8 & 7.8 & 7.8 \\
\hline Digestible Tryptophan & 2.6 & 2.6 & 2.6 & 2.6 & 2.6 & 2.6 & 2.6 & 2.6 \\
\hline Sodium & 2.2 & 2.2 & 2.2 & 2.2 & 2.2 & 2.2 & 2.2 & 2.2 \\
\hline Calcium & $9.0(8.9)$ & $9.0(8.3)$ & $9.0(8.5)$ & $9.0(9.4)$ & $5.0(4.6)$ & $7.0(6.1)$ & $9.0(8.9)$ & $11.0(10.4)$ \\
\hline Total Phosphorus & $4.7(4.9)$ & $5.7(6.2)$ & $6.7(6.8)$ & $7.7(8.1)$ & $4.7(4.9)$ & $5.7(6.0)$ & $6.7(7.0)$ & $7.7(8.2)$ \\
\hline Phytic Acid & $2.2(2.1)$ & $2.2(2.1)$ & $2.2(2.0)$ & $2.2(2.0)$ & $2.2(2.1)$ & $2.2(2.1)$ & $2.2(2.0)$ & $2.2(2.0)$ \\
\hline Non-phytate Phosphorus ${ }^{(10)}$ & $2.5(2.8)$ & $3.5(4.1)$ & $4.5(4.8)$ & $5.5(6.1)$ & $2.5(2.8)$ & $3.5(3.9)$ & $4.5(5.0)$ & $5.5(6.2)$ \\
\hline Ca:nPP ratio & $\begin{array}{c}3.6: 1 \\
(3.2: 1)\end{array}$ & $\begin{array}{l}2.6: 1 \\
(2.0: 1)\end{array}$ & $\begin{array}{l}2.0: 1 \\
(1.8: 1)\end{array}$ & $\begin{array}{l}1.6: 1 \\
(1.5: 1)\end{array}$ & $\begin{array}{l}2.0: 1 \\
(1.6: 1)\end{array}$ & $\begin{array}{c}2.0: 1 \\
(1.6: 1)\end{array}$ & $\begin{array}{c}2.0: 1 \\
(1.8: 1)\end{array}$ & $\begin{array}{l}2.0: 1 \\
(1.7: 1)\end{array}$ \\
\hline
\end{tabular}

${ }^{(1)} \mathrm{Ca}$ fixed at $9.0 \mathrm{~g}$ per kg of diet, independently of the nPP concentration. ${ }^{(2)} \mathrm{Ca}$ varying together with $\mathrm{nPP}$ to keep a fixed Ca:nPP ratio. ${ }^{(3)}$ Provided per $\mathrm{kg}$ of the complete diet: $75 \mathrm{mg}$ of $\mathrm{Mn}\left(\mathrm{as} \mathrm{MnSO}_{4}\right), 70 \mathrm{mg}$ of $\mathrm{Zn}\left(\right.$ as $\left.\mathrm{ZnSO}_{4}\right), 50 \mathrm{mg}$ of Fe (as FeSO ), $8 \mathrm{mg}$ of Cu (as $\mathrm{Cu} \mathrm{SO}_{4}$ ), and $0.75 \mathrm{mg}$ of I (as $\left.\mathrm{Ca}\left(\mathrm{IO}_{3}\right)_{2}\right)$. ${ }^{(4)}$ Provided per kg of the complete diet: retinyl acetate, $5600 \mathrm{IU}$; cholecalciferol, $1200 \mathrm{IU}$; DL- $\alpha$-tocopheryl acetate, $10 \mathrm{IU}$; thiamin, $1.55 \mathrm{mg}$; riboflavin, $4.00 \mathrm{mg}$; pyridoxine, $2.08 \mathrm{mg}$; pantothenic acid, $10.40 \mathrm{mg}$; menadione sodium bisulphite, $1.20 \mathrm{mg}$; folic acid, 0,65 mg; niacin, 28,00 mg; cyanocobalamin, $8 \mu \mathrm{g}$; selenium, $300 \mu \mathrm{g}$; and antioxidant, 0,50 mg. ${ }^{(5)}$ Coxistac ${ }^{\circledR}$ 12\% Granular (Phibro Animal Health Corporation, Guarulhos, São Paulo, Brazil). Supplied per kg of diet: Salinomycin, 60 mg; Calcium carbonate, 0.40g. ${ }^{(6)}$ SURMAX 100 (Elanco Saúde Animal, Greenfield, Indiana, EUA). Supplied per kg of diet: Avilamicin, $10 \mathrm{mg} .{ }^{(7)}$ Butyl hydroxy toluene (EMFAL Especialidades Químicas, Betim, Minas Gerais, Brazil). Supplied per kg of diet: Butylated hydroxytoluene, $99 \mathrm{mg}\left(\mathrm{as} \mathrm{C}_{15} \mathrm{H}_{24} \mathrm{O}\right) .{ }^{(8)}$ Analyzed in triplicate. ${ }^{(9)}$ According to Rostagno et al. $(2005) .{ }^{(10)}$ Determined $n P P$ concentration based on analyzed $\mathrm{P}$ minus analyzed phytate $\mathrm{P}$. 
Table 2. Growth performance of male broilers fed diets containing different non-phytate phosphorus (nPP) concentrations, keeping or not the Ca:nPP ratio of diets, under thermoneutral conditions.

\begin{tabular}{|c|c|c|c|c|c|c|c|c|c|c|c|}
\hline \multirow{2}{*}{ Variable } & \multicolumn{4}{|c|}{ nPP concentration $(\%)$} & \multirow{2}{*}{$\begin{array}{c}\text { Ca supply } \\
\text { regimen }\end{array}$} & \multirow{2}{*}{ Average } & \multicolumn{3}{|c|}{$p$-value } & \multirow{2}{*}{ Regression $^{(4)}$} & \multirow{2}{*}{$\mathbf{S E M}^{(5)}$} \\
\hline & 0.25 & 0.35 & 0.45 & 0.55 & & & nPP & $\mathbf{C a}$ & $\mathrm{nPP} \times \mathrm{Ca}$ & & \\
\hline \multirow[t]{2}{*}{ FI, $g^{(1)}$} & 891 & 924 & 940 & 926 & $\mathrm{CaF}$ & 920 & 0.005 & 0.942 & 0.734 & $\mathrm{Q}^{* *}$ & 8.82 \\
\hline & & & & & $\mathrm{CaV}$ & 920 & & & & & \\
\hline \multirow[t]{2}{*}{$\mathrm{BWG}, \mathrm{g}^{(2)}$} & 598 & 653 & 678 & 671 & $\mathrm{CaF}$ & 660 & $<0.001$ & 0.082 & 0.509 & $\mathrm{Q}^{* *}$ & 10.71 \\
\hline & & & & & $\mathrm{CaV}$ & 640 & & & & & \\
\hline \multirow[t]{2}{*}{$\mathrm{FCR}^{(3)}$} & 1.44 & 1.38 & 1.37 & 1.39 & $\mathrm{CaF}$ & $1.40^{\mathrm{b}}$ & $<0.001$ & 0.004 & 0.031 & $\mathrm{Q}^{*}$ & 0.01 \\
\hline & 1.54 & 1.45 & 1.41 & 1.37 & $\mathrm{CaV}$ & $1.45^{\mathrm{a}}$ & & & & $\mathrm{L}^{* *}$ & 0.01 \\
\hline
\end{tabular}

(1)FI: feed intake, as-fed basis. ${ }^{(2)} \mathrm{BWG}$ : body weight gain. ${ }^{(3)} \mathrm{FCR}$ : feed conversion rate, based on live bird days within each period. ${ }^{(4)} Q$ : quadratic effect; $L$ : linear effect. Means followed by different letters for each variable between the Ca supply regimens employed differ by the $\mathrm{F}$ test $(p<0.05) .{ }^{*} p<0.05 ; * * p<0.01 .{ }^{* 5}$ SEM: standard error of the mean; $\mathrm{n}=8$.

nPP concentrations, in order to maintain a fixed Ca:nPP ratios $(\mathrm{CaV})$, were used. The $\mathrm{nPP}$ content of feed ingredients was calculated as $33 \%$ of total $\mathrm{P}$ (Rostagno et al., 2005).

The levels of dicalcium phosphate, limestone and inert material (silica sand) were adjusted to obtain the desired nPP and $\mathrm{Ca}$ levels, then experimental diets were analysed in triplicate for $\mathrm{Ca}$ by atomic absorption spectrophotometry (method 4.8.03; AOAC, 2000), and total $\mathrm{P}$ by the colorimetric method (method 3.4.11; AOAC, 2000). Phytate P (PP) content of the basal diet was analyzed according to the ferric precipitation method as described by Ellis et al. (1977). All experimental diets were isoenergetic, isoproteic and isoaminoacidic. Animals were fed ad libitum and had free access to water throughout the experimental period.

\section{Procedures}

Pen weights were recorded at the beginning ( $8 \mathrm{~d}$ of age) and at the end ( $21 \mathrm{~d}$ of age) of the experimental period. Dead birds were weighed and removed from the pens twice daily and dead weights were used to correct feed conversion ratio (FCR). At the end of the experimental period ( $21 \mathrm{~d}$ ), all birds and feeders were weighed to determine feed intake (FI), body weight gain (BWG), and FCR for the entire experimental period (8-21 d). Also, at $21 \mathrm{~d}$ of age, two broiler chickens from each battery cage, closest to the cage average were selected, fasted for $12 \mathrm{~h}$, and then slaughtered by cervical dislocation to remove the right tibia. The right tibia was removed, forming a "pool" of two samples per replicate, and soft tissue and cartilaginous caps were removed. Samples were then pre-dried at $65^{\circ} \mathrm{C}$ in a drying oven for $72 \mathrm{~h}$ to reduce the moisture content below $15 \%$ enabling mechanical processing and sample conservation (Detmann et al., 2012).

Once dried, tibias were defatted with petroleum ether using Soxhlet apparatus for $4 \mathrm{~h}$. Dry-defatted tibias were then placed in a $105^{\circ} \mathrm{C}$ drying oven for $24 \mathrm{~h}$ and ashed at $600^{\circ} \mathrm{C}$ for $8 \mathrm{~h}$. Ashed tibias were analyzed in triplicate for $\mathrm{Ca}$ by atomic absorption spectrophotometry (method 4.8.03; AOAC, 2000) and for $\mathrm{P}$ by the colorimetric method (method 3.4.11; AOAC, 2000). The amount of phosphorus (TibP), calcium (TibCa) and ash (TibAsh) were expressed as $\mathrm{g} / \mathrm{kg}$ of dry defatted tibias.

\section{Statistical analyses}

Data were analyzed using the GLM procedure of JMP PRO 10 (SAS Inst, 2012). The effects included in the model were: nPP level, Ca supply regimen and the interaction between those factors (nPP and Ca supply regimen). The results for all treatments were presented or not according to the interaction significance and the estimated nPP requirement for male broilers from 8 to $21 \mathrm{~d}$ of age were established by means of linear and quadratic regression model as the best fit obtained for each variable. Tukey's adjustment test was applied to the means of the $\mathrm{Ca}$ supply regimen factor in order to determine $p$-values. Significance was declared at $p<0.05$.

\section{Results}

During the experimental period, air temperature inside the facilities was kept at $29.08 \pm 0.70^{\circ} \mathrm{C}$ and 27.28 $\pm 0.94^{\circ} \mathrm{C}$ and relative air humidity at $62.35 \pm 4.07 \%$ and $61.32 \pm 4.73 \%$, corresponding to a calculated BGTH index of $78.4 \pm 0.66$ and $76.3 \pm 0.91$, respectively, for the periods from 8 to 15 and 16 to $21 \mathrm{~d}$ of age.

The results of performance and bone mineralization of birds kept in thermoneutral environment conditions and fed diets with different levels of nPP, keeping or not a fixed Ca:nPP ratio, are shown in Tables 2 and 3 , respectively. 
Table 3. Bone mineralization of male broilers fed diets containing different non-phytate phosphorus (nPP) concentrations, keeping or not the Ca:nPP ratio of diets, under thermoneutral conditions.

\begin{tabular}{|c|c|c|c|c|c|c|c|c|c|c|c|}
\hline \multirow{2}{*}{ Variable } & \multicolumn{4}{|c|}{ nPP concentration $(\%)$} & \multirow{2}{*}{$\begin{array}{l}\text { Ca supply } \\
\text { regimen }\end{array}$} & \multirow{2}{*}{ Average } & \multicolumn{3}{|c|}{$p$-value } & \multirow{2}{*}{ Regression $^{(5)}$} & \multirow{2}{*}{$\mathbf{S E M}^{(6)}$} \\
\hline & 0.25 & 0.35 & 0.45 & 0.55 & & & nPP & $\mathbf{C a}$ & $\mathbf{n P P} \times \mathbf{C a}$ & & \\
\hline \multirow{2}{*}{$\begin{array}{l}\text { TibP, } \\
\mathrm{g} / \mathrm{kg}^{(1)}\end{array}$} & 61.24 & 74.44 & 80.95 & 78.00 & $\mathrm{CaF}$ & 73.66 & $<0.001$ & $<0.001$ & $<0.001$ & $\mathrm{Q}^{* *}$ & 0.93 \\
\hline & 69.35 & 76.35 & 80.98 & 78.70 & $\mathrm{CaV}$ & 76.34 & & & & $\mathrm{Q}^{* *}$ & 0.85 \\
\hline \multirow{2}{*}{$\begin{array}{l}\text { TibCa, } \\
\mathrm{g} / \mathrm{kg}^{(2)}\end{array}$} & 129.75 & 153.50 & 151.00 & 151.00 & $\mathrm{CaF}$ & $146.31^{\mathrm{b}}$ & $<0.001$ & $<0.001$ & 0.020 & $\mathrm{Q}^{* *}$ & 1.57 \\
\hline & 145.50 & 160.38 & 152.88 & 155.88 & $\mathrm{CaV}$ & $153.66^{\mathrm{a}}$ & & & & $\mathrm{Q}^{* *}$ & 2.42 \\
\hline \multirow{2}{*}{$\begin{array}{l}\text { TibAsh, } \\
\%^{(3)}\end{array}$} & 37.98 & 45.04 & 46.57 & 45.44 & $\mathrm{CaF}$ & 43.76 & $<0.001$ & 0.710 & $<0.001$ & $\mathrm{Q}^{* *}$ & 0.43 \\
\hline & 40.23 & 43.36 & 45.69 & 46.24 & $\mathrm{CaV}$ & 43.88 & & & & $\mathrm{~L}^{* *}$ & 0.44 \\
\hline \multirow{2}{*}{$\begin{array}{l}\text { TibCa: } \\
\text { TibP }^{(4)}\end{array}$} & 2.11 & 2.08 & 1.88 & 1.96 & $\mathrm{CaF}$ & 2.00 & $<0.001$ & 0.410 & 0.790 & $\mathrm{Q}^{*}$ & 0.02 \\
\hline & & & & & $\mathrm{CaV}$ & 2.02 & & & & & \\
\hline
\end{tabular}

(1)TibP: amount of P in the dry defated tibia. ${ }^{(2)}$ TibCa: amount of Ca in the dry defated tibia. ${ }^{\left({ }^{(}\right)}$TibAsh: amount of ash in the dry defated tibia. ${ }^{(4)} \mathrm{Ca}$ :P ratio in the dry defated tibia. ${ }^{(5)} Q$ : quadratic effect; $L$ : linear effect. Means followed by different letters for each variable between the Ca supply regimens employed differ by the $\mathrm{F}$ test $(p<0.05) .{ }^{*} p<0.05 ;{ }^{* *} p<0.01$. ${ }^{(6)} \mathrm{SEM}$ : standard error of the mean; $\mathrm{n}=8$.

No $n P P \times$ Ca supply regimen interaction $(p>0.05)$ was found on FI, BWG and TibCa:TibP data; however, an interaction effect $(p<0.05)$ was observed on FCR, TibP, TibCa and TibAsh (Table 4).

The $\mathrm{nPP}$ levels tested significantly affected $(p<0.01)$ FI and BWG of broilers regardless of the Ca supply regimen adopted, which increased quadraticaly to the estimated level of 0.453 and $0.480 \% \mathrm{nPP}$ for FI and BWG, respectively (Table 2).

When $\mathrm{CaF}$ diets were used, nPP levels significantly influenced $(p<0.01) \mathrm{FCR}$, which increased quadratically to the estimated levels of $0.438 \% \mathrm{nPP}$. However, when

Table 4. Non-phytate phosphorus (nPP) requirement of male broilers from 8 to $21 \mathrm{~d}$ of age, keeping or not the Ca:nPP ratio, under thermoneutral conditions.

\begin{tabular}{|c|c|c|c|c|}
\hline Variable & Equation & $p$-value & $R^{2}$ & nPP(5) \\
\hline \multicolumn{5}{|c|}{ Non-significant $\mathrm{nPP} \times \mathrm{Ca}$ interaction } \\
\hline \multicolumn{5}{|l|}{ Performance parameters } \\
\hline Feed intake (FI) & $\mathrm{Yij}=698.0+1061 \mathrm{nPP}-1172 \mathrm{nPP}^{2}$ & 0.001 & 0.21 & 0.453 \\
\hline Body weight gain (BWG) & $\mathrm{Yij}=326.2+1473 \mathrm{nPP}-1536 \mathrm{nPP}^{2}$ & 0.006 & 0.36 & 0.480 \\
\hline \multicolumn{5}{|l|}{ Bone mineralization } \\
\hline TibCa:TibP ratio deposited ${ }^{(1)}$ & $Y_{i j}=2.666-2.816 n P P+2.713 n P^{2}$ & 0.045 & 0.36 & 0.519 \\
\hline \multicolumn{5}{|c|}{ Significant $\mathrm{nPP} \times \mathrm{Ca}$ interaction } \\
\hline \multicolumn{5}{|l|}{ Ca supply regimen: $\mathrm{CaF}$} \\
\hline \multicolumn{5}{|l|}{ Performance parameters } \\
\hline Feed conversion rate (FCR) & $Y i j=1.769-1.833 n P P+2.093 n P^{2}$ & 0.012 & 0.30 & 0.438 \\
\hline \multicolumn{5}{|l|}{ Bone characteristics } \\
\hline $\operatorname{TibP}^{(2)}$ & $Y i j=-8.617+379.8 n P P-403.7 n P^{2}$ & $<0.001$ & 0.89 & 0.470 \\
\hline $\mathrm{TibCa}^{(3)}$ & $\mathrm{Yij}=34.23+536.2 \mathrm{nPP}-593.8 \mathrm{nPP}^{2}$ & $<0.001$ & 0.73 & 0.452 \\
\hline $\operatorname{TibAsh}^{(4)}$ & $Y i j=3.991+187.7 n P P-204.7 n P^{2}$ & $<0.001$ & 0.88 & 0.459 \\
\hline \multicolumn{5}{|l|}{ Ca supply regimen: $\mathrm{CaV}$} \\
\hline \multicolumn{5}{|l|}{ Performance parameters } \\
\hline Feed conversion rate (FCR) & $\mathrm{Yij}=1.672-0.5723 \mathrm{nPP}$ & $<0.001$ & 0.48 & - \\
\hline \multicolumn{5}{|l|}{ Bone mineralization } \\
\hline TibP & $Y i j=29.07+218.2 n P P-231.9 n P^{2}$ & $<0.001$ & 0.76 & 0.471 \\
\hline TibCa & $\mathrm{Yij}=100.4+261.1 \mathrm{nPP}-296.9 \mathrm{nPP}{ }^{2}$ & 0.054 & 0.20 & 0.440 \\
\hline TibAsh & $\mathrm{Yij}=35.74+20.35 \mathrm{nPP}$ & $<0.001$ & 0.74 & - \\
\hline
\end{tabular}

(1)Ca: P ratio in the dry defated tibia. ${ }^{(2)}$ TibP: amount of P in the dry defated tibia. ${ }^{(3)}$ TibCa: amount of Ca in the dry defated tibia. ${ }^{(4)}$ TibAsh: amount of ash in the dry defated tibia. ${ }^{(5)}$ Requirement of dietetic nPP (\%). 
the $\mathrm{CaV}$ diet was provided, FCR increased linearly $(p<0.01)$.

The nPP levels influenced FCR of birds, which improved $(p<0.05)$ quadraticaly to the estimated level of $0.438 \% \mathrm{nPP}$, when $\mathrm{CaF}$ diets were used, and linearly $(p<0.01)$ with $\mathrm{CaV}$ diets. Also, animals fed $\mathrm{CaV}$ diets had an increased $(p<0.05)$ average FCR by $2.86 \%$, when compared with the animals fed $\mathrm{CaF}$ diets.

The nPP levels tested influenced $(p<0.05)$ TibP and TibCa content, which increased quadraticaly up to the estimated level of, respectively, $0.470 \% \mathrm{nPP}$ for both Ca regimen tested and 0.452 and $0.440 \%$, respectively, with $\mathrm{CaF}$ and $\mathrm{CaV}$ diets. As for TibAsh content, it was significant affected $(p<0.05)$ by the nPP levels tested, which increased quadraticaly up to the estimated nPP level of $0.459 \%$ with $\mathrm{CaF}$ diets and linearly with the use of $\mathrm{CaV}$ diets. Also, the average TibP of broilers did not differ $(p>0.05)$ between the groups of birds fed the $\mathrm{CaF}$ and $\mathrm{CaV}$ diets, whereas the same was not observed for the average TibCa, where a significant difference was observed $(p<0.01)$ among animals fed the $\mathrm{CaF}$ and $\mathrm{CaV}$ diets, as the $\mathrm{CaV}$ diet provided an average TibCa $5.02 \%$ higher $(p<0.01)$ when compared to the $\mathrm{CaF}$ diet.

Regardless of the Ca supply regimen adopted the nPP levels tested had a significant effect $(p<0.01)$ on TibCa:TibP, which decreased $(p<0.05)$ up to the estimated level of 0.519 .

\section{Discussion}

According to the Roncbi (2004) and Cobb Vantress (2012), air temperatures ranging from 26 to $29^{\circ} \mathrm{C}$ with relative air humidity of $60 \%$ characterize an optimal environmental condition for broiler chickens from 8 to $21 \mathrm{~d}$. In addition, according to Valério et al. (2003) and Lana et al. (2005), BGTH index values ranging from 74 to 83 are suitable for this category. Therefore, based on this information, we can infer that in this study all birds were kept in a thermoneutral environment condition.

Similar FI response has also been reported by Runho et al. (2001), Persia \& Saylor (2006), Kill et al. (2008), Puppo et al. (2008) and Maia et al. (2009), who also found that available phosphorus (aP) levels influence voluntary FI of broilers fed diets with fixed $\mathrm{Ca}$, independently of sex and strain of birds. On the contrary, when working with broilers, keeping a fixed 2:1 Ca to aP ratio, Yan et al. (2000), Bünzen et al. (2008) and Mello et al. (2012) failed to observe any aP effect on FI.

According to Rama Rao et al. (2006), the negative effect of low aP concentration on the voluntary FI of broilers is dependent on the Ca level used. Also, Qian et al. (1997) stated that the wider the Ca:aP ratio, the lowest is the FI of broilers. Several authors (Kill et al., 2008; Maia et al., 2009; Cardoso et al., 2010) identified that the highest FI for broiler chickens were obtained with diets in which the Ca:aP ratio were, respectively, 2:1, 1,96:1 and 2,12:1 while working with fixed $\mathrm{Ca}$ concentrations and increasing aP levels.

The estimated nPP levels that provided the best BWG results of broilers did not differ $(p>0.05)$ between groups of birds fed $\mathrm{CaF}$ and $\mathrm{CaV}$ diets. According to Tamin et al. (2004), birds nPP requirement is influenced by the $\mathrm{Ca}$ level of the diet, due to its possible interaction with phytic phosphorus, negatively influencing the digestibility of both.

The nPP level that provided best BWG result in this study $(0.480 \%)$ was superior to those obtained by Brugalli et al. (1999) and Maia et al. (2009), 0.45\% and $0.46 \%$, respectively, for broilers from 8 to $21 \mathrm{~d}$ of age fed $\mathrm{CaF}$ diets, and Mello et al. (2012), corresponding to $0.19 \%$, for broilers from 11 to $21 \mathrm{~d}$ of age fed $\mathrm{CaV}$ diets. Rostagno et al. (2011) proposed the level of $0.401 \%$ $\mathrm{nPP}$ as the requirement for broilers from 8 to $21 \mathrm{~d}$ for best performance. The low Ca level $(8.41 \mathrm{~g} / \mathrm{kg})$, when compared to the present study $(8.99 \mathrm{~g} / \mathrm{kg})$, proposed by those authors is one of the factors that would justify the lower $\mathrm{nPP}$ requirement value proposed.

Similarly to our results, Brugalli et al. (1999), Runho et al. (2001), and Maia et al. (2009) also found a positive influence of the aP levels on FCR of broilers from 8 to $21 \mathrm{~d}$ of age while working with fixed Ca concentration. In contrast, Kill et al. (2008), Puppo et al. (2008) and Cardoso et al. (2010), under the same circumstances, did not identify any significant FCR variation. Also, in the case of diets with fixed Ca:nPP ratio, a similar result was also obtained by Mello et al. (2012).

The inconsistency of the results showed can be attributed, among other things, to the variation in initial body weight of chicks used in the different studies. As reported by Angel (2011), there are several factors that can justify the different results in determining the nutritional $\mathrm{nPP}$ requirements, especially the growth rate of birds during the experimental period.

It was also evidenced in this study that in the two lowest nPP levels $(0.25$ and $0.35 \%)$ tested, the absolute FCR values were, respectively, 6.94 and $5.07 \%$ higher in birds fed $\mathrm{CaV}$ diets. This may indicate $\mathrm{Ca}$ deficiency when diets with $\mathrm{CaV}$ were used.

Also, in the lowest levels of nPP $(0.25 \%)$ tested, the absolute values of TibP were $13.24 \%$ higher in birds fed diets with $\mathrm{CaV}$ what indicates the importance of a proper Ca:nPP ratio for an ideal bone mineralization. The obtained data on TibCa and TibP in the lowest nPP level tested $(0.25 \%)$ showed that birds fed diets with $\mathrm{CaV}$ prioritized the deposition of both minerals in the tibia at the expense of growth. 
As for TibCa, when observing the lowest $(0.25 \%)$ and highest $(0.55 \%) \mathrm{nPP}$ levels tested, it was found that $\mathrm{Ca}$ deposition was compromised when using diets with CaF. Thus, it can be deduced that the deposition of calcium in the bone with deficiently nPP levels or above the requirement for optimal growth $(0.45 \%)$ is dependent on a proper Ca:nPP ratio, which in this study was 1.6:1.

As for TibAsh content, a significant effect of the increasing nPP levels tested was also observed by Gomes et al. (1993), Lima (1995) and Runho et al. (2001). The results obtained for TibAsh when the lowest $\mathrm{nPP}$ concentration was tested $(0.25 \%)$, suggests that once the Ca:nPP ratio is maintained at 1.6:1, birds tend to improve bone mineralization even if those minerals are deficient.

Although bone mineralization occurs most efficiently when Ca:nPP ratio is maintained, Cardoso et al. (2010) found that broiler chickens fed diets deficient in $\mathrm{Ca}$ and aP had a lower TibAsh percentage due to insufficient quantity of those minerals studied for a proper mineralization.

The average values of TibCa:TibP $(2.00: 1 \times 2.02: 1)$ did not differ $(p>0.05)$ when using diets with $\mathrm{CaF}$ or $\mathrm{CaV}$. Since Ca:nPP ratio in the diet which has been used $\mathrm{CaF}$ ranged from 1.63 to 3.60 , it can be inferred that tibia P deposition occurs simultaneously with $\mathrm{Ca}$ in a proportion close to $2: 1$, characterizing interdependence between these minerals. Studying the nPP levels in broiler chicks from 8 to $21 \mathrm{~d}$ old on thermoneutral environment conditions, Maia et al. (2009) also found proportionality in TibCa:TibP ratio $(2: 1)$, regardless of their ratio in the experimental diets.

Based on the results, it is clear that the levels of dietary $\mathrm{Ca}$ and $\mathrm{nPP}$ are not responsible for this regulation in the TibCa:TibP ratio deposited. In this sense, Crenshaw et al. (2011) identified the bone as the main site of synthesis of Fibroblast Growth Factor 23 (FGF 23), responsible for both renal $\mathrm{P}$ transport and by regulating vitamin $D_{3}$ activation, characterizing the bone tissue as an endogenous gland.

The best performance and bone mineralization of male broilers reared at thermoneutral conditions from 8 to $21 \mathrm{~d}$ of age were at nPP concentration of, respectively, 0.480 and $0.459 \%$ with the diet in which the level of $\mathrm{Ca}$ was kept fixed, corresponding to the estimated nPP intake of 4.46 and $4.26 \mathrm{~g}$, and $0.550 \%$ independently of the $\mathrm{Ca}$ supply regimen adopted with the diet in which $\mathrm{Ca}$ varied proportionally to the nPP level, keeping a fixed Ca:nPP ratio of 1.6:1, corresponding to the estimated nPP intake of $5.14 \mathrm{~g}$. In conclusion, the results from the present study indicate that, under thermoneutral conditions, $\mathrm{CaV}$ diets negatively affected growth performance of broilers, while positively affecting bone mineralization especially when low nPP levels are applied.

\section{References}

Angel R, 2011. Calcium and phosphorus requirements in broilers. III Int Symp on Nutritional Requirements of Poultry and Swine, Viçosa (Brazil), March 29-31. pp: 77-96.

Ankra-Badu GA, Aggrey SE, Pesti GM, Bakalli RI, Edwards HM, 2004. Modeling of parameters affecting phytate phosphorus bioavailability in growing birds. Poult Sci 83: 1083-1088. https://doi.org/10.1093/ps/83.7.1083

AOAC, 2000. Official methods of analysis, $17^{\text {th }} \mathrm{edn}$. AOAC Int, MD, USA.

Boling SD, Douglas MW, Johnson ML, Wang X, Parsons CM, Koelkebeck KW, Zimmerman RA, 2000. The effects of dietary available phosphorus levels and phytase on performance of young and older laying hens. Poul Sci 79: 224-230. https://doi.org/10.1093/ps/79.2.224

Brugalli I, Silva DJ, Albino LFT, Gomes PC, Rostagno HS, Silva MA, 1999. Available phosphorus requirement and effect of particle size on phosphorus bioavailability from meat and bone meal for broiler chicks. Rev Bras Zootec 28: 12881296. https://doi.org/10.1590/S1516-35981999000600016

Buffington DE, Collazo-Arocho A, Canton GH, Pitt D, 1981. Black globe-humidity index (BGHI) as comfort equation for dairy cows. Am Soc Agric Eng 24: 711-714.

Bünzen S, Rostagno HS, Borsatto CG, Pessõa GBS, Carvalho TA, Messias RKG, 2008. Exigência de fósforo disponível para frangos de corte de 22 a 35 dias de idade, mantendo-se a relação Ca:Pdisp em 2:1. Conferência Apinco de Ciência e Tecnologia Avícola, Campinas (Brazil), May 27-29. pp: 45.

Cardoso A Jr, Rodrigues PB, Bertechini AG, Freitas RTF, Lima RR, Lima GFR, 2010. Levels of available phosphorus and calcium for broilers from 8 to 35 days of age fed rations containing phytase. Rev Bras Zootec 39: 1237-1245. https:// doi.org/10.1590/S1516-35982010000600011

Cobb Vantress, 2012. Cobb Broiler Management Guide. CobbVantress Inc, Siloam Springs, AR, USA.

Crenshaw TD, Rortvedt LA, Hassen Z, 2011. Triennial Growth Symp: A novel pathway for vitamin D-mediated phosphate homeostasis: Implications for skeleton growth and mineralization. J Anim Sci 89: 1957-1964. https://doi. org/10.2527/jas.2010-3411

Cromwell GL, Stahly TS, Monegue HJ, 1989. Effect of source and level of copper on performance and liver copper, stores in weanling pigs. J Anim Sci 67: 2996-3002. https://doi. org/10.2527/jas1989.67112996x

Detmann E, Souza MA, Valadares Filho SC, Queiroz AC, Berchielli TT, Saliba EOS, Cabral LS, Pina DS, Ladeira MM, Azevedo JAG, 2012. Métodos para análise de alimentos, $1^{\text {st }}$ ed. Suprema, Visconde do Rio Branco, Brazil. 214 pp. 
Ellis R, Morris ER, Philpot C, 1977. Quantitative determination of phytate in the presence of high inorganic phosphate. Anal Biochem 77: 536-539. https://doi.org/10.1016/00032697(77)90269-X

Gomes PC, Gomes MFM, Lima GJMM, Bellaver C, 1993. Exigência de fósforo e sua disponibilidade nos fosfatos monoamônio e monocálcico para frangos de corte até 21 dias de idade. Rev Bras Zootec 22: 755-763.

Kill JL, Donzele JL, Cardoso EF, Haddade I, Rossoni MC, Haese D, Pires AF, Lima AL, 2008. Exigência de fósforo para frangos de corte de 7 a 28 dias de idade. Congresso Brasileiro de Zootecnia, João Pessoa (Brazil), May 26-30.

Lana SRV, Oliveira RFM, Donzele JL, Gomes PC, Vaz RGMV, Rezende WO, 2005. Requirements of dietary digestible lysine for broilers from 22 to 42 days old on thermoneutral environment. Rev Bras Zootec 34: 1614-1623. https://doi. org/10.1590/S1516-35982005000500023

Lima IL, 1995. Disponibilidade de fósforo e de flúor de alguns alimentos e exigência nutricional de fósforo para frangos de corte. Doctoral thesis. Univ. Federal de Viçosa, Viçosa, Brazil. 121 pp.

Maia APA, Antunes MVL, Campos PHRF, Souza MF, Balbino EM, Oliveira RFM, Donzele JL, 2009. Available phosphorus levels in diets for male broilers from 8 to 21 days of age kept in high temperature and thermoneutral environment. Congr Int de Zootecnia, Águas de Lindoia (Brazil), May 18-22.

Mello HHC, Gomes PC, Rostagno HS, Albino LFT, Rocha TC, Almeida RL, Calderano AA, 2012. Dietary requirements of available phosphorus in growing broiler chickens at a constant calcium:available phosphorus ratio. Rev Bras Zootec 41 (11): 2323-2328. https://doi.org/10.1590/S151635982012001100004

Persia ME, Saylor WW, 2006. Effects of broilers strain, dietary nonphytate phosphorus, and phytase supplementation on chick performance and tibia ash. J Appl Poult Res 15: 72-81. https://doi.org/10.1093/japr/15.1.72

Puppo D, Cardoso EF, Kill JL, Haese D, Rossoni MC, Haddade I, 2008. Exigência de fósforo para frangos de corte dos 8 aos 21 dias de idade. V Congr Nordestino de Produção Animal, Aracaju (Brazil), Nov 24-27.

Qian H, Kornegay ET, Denbow DM, 1997. Utilization of phytate phosphorusand calcium as influenced by microbial phytase, cholecalciferol, and the calcium: total phosphorus ratio in broilers diets. Poult Sci 76: 37-46. https://doi.org/10.1093/ ps/76.1.37

Rama Rao SV, Ramasubba Reddy V, 2003. Relative bioavailability and utilization of phosphatic fertilizers as sources of phosphorus in broilers and layers. Br Poult Sci 44 (1): 96103. https://doi.org/10.1080/0007166031000085274

Rama Rao SV, Raju MVLN, Reddy MR, Pavani P, 2006. Interaction between dietary calcium and non-phytate phosphorus levels on growth, bone mineralization and mineral excretion in commercial broilers. Anim Feed Sci Technol 131: 133-148. https://doi.org/10.1016/j.anifeedsci.2006.02.011
Ronchi C, 2004. Principais práticas de manejo para aves recémnascidas. Revista AveWorld 6: 26-30.

Rostagno HS, Albino LFT, Donzele JL, Gomes PC, Oliveira RFM, Lopes DC, Soares AF, Barreto SLT, 2005. Brazilian tables for poultry and swine: composition of feedstuffs and nutritional requirements, $2^{\text {nd }}$ ed. UFV, Viçosa, Brazil. 186 pp.

Rostagno HS, Albino LFT, Donzele JL, Gomes PC, Oliveira RFM, Lopes DC, Soares AF, Barreto SLT, Euclides RF, 2011. Brazilian tables for poultry and swine: composition of feedstuffs and nutritional requirements, $3^{\text {rd }}$ ed. UFV, Viçosa, Brazil. 252 pp.

Runho RC, Gomes PC, Rostagno HS, Albino LFT, Lopes PS, Pozza PC, 2001. Available phosphorus requirement of male and female broilers from 1 to 21 days of age. Rev Bras Zootec 30: 187-196. https://doi.org/10.1590/S151635982001000100027

Saraiva A, Donzele JL, Oliveira RF, Abreu ML, Silva FC, Guimarães SE, Kim SW, 2012. Phosphorus requirements for 60- to 100-kg pigs selected for high lean deposition under different thermal environments. J Anim Sci 90: 1499-1505. https://doi.org/10.2527/jas.2010-3623

SAS Inst, 2012. JMP Pro 10 Basic Analysis and Graphing. SAS Institute Inc., Cary, NC, USA.

Sethi PK, McMurtry JP, Pesti GM, Edwards HM Jr, Aggrey SE, 2008. Physiological responses to divergent selection for phytate phosphorus bioavailability in a randombred chicken population. Poult Sci 87: 2512-2516. https://doi.org/10.3382/ ps.2008-00190

Silva JHV, Araújo JA, Goulart CC, Costa FGP, Sakomura NK, Martins TDD, 2008. Calcium:available phosphorus ratio and phytase levels for semi heavy laying hens in the first and second posture cycle. Rev Bras Zootec 37 (12): 2166-2172. https://doi.org/10.1590/S1516-35982008001200013

Tamin NM, Angel R, Christman M, 2004. Influence of dietary calcium and phytase on phytate phosphorus hydrolyses in broiler chickens. Poult Sci 83 (8): 1358-1367. https://doi. org/10.1093/ps/83.8.1358

Valério SR, Oliveira RFM, Donzele JL, Albino LFT, Orlando UAD, Vaz RGMV, 2003. Digestible lysine levels in diets maintaining or not the relationship of amino acids for broilers from 1 to 21 days of age kept under heat stress. Rev Bras Zootec 32 (2): 361-371.

Xie M, Wang SX, Hou SS, Huang W, 2009. Interaction between dietary calcium and non-phytate phosphorus on growth performance and bone ash in early White Pekin ducklings. Anim Feed Sci Technol 151: 161-166. https://doi. org/10.1016/j.anifeedsci.2009.01.005

Yan F, Kersey JH, Fritts CA, Waldroup PW, Stilborn HL, Crum RC Jr, Rice DW, Raboy V, 2000. Evaluation of normal yellow dent corn and high available phosphorus corn in combination with reduced dietary phosphorus and phytase supplementation for broilers grown to market weights in litter pens. Poult Sci 79 (9): 1282-1289. https://doi.org/10.1093/ ps/79.9.1282 